\title{
Should Households Base Asset Decumulation Strategies on Required Minimum Distribution Tables?
}

\author{
Wei Sun ${ }^{\mathrm{a}}$ and Anthony Webb ${ }^{\mathrm{b}}$ \\ ${ }^{a}$ Hanqing Advanced Institute of Economics and Finance and School of Finance, Renmin University of China, Ming \\ De Main Building 512D, 59 Zhongguancun Street, Beijing 100872, China. \\ ${ }^{\mathrm{b}}$ Center for Retirement Research, Boston College, 258 Hammond St, Chestnut Hill, MA 02467, U.S.A.
}

Retired households must trade off the risk of outliving their wealth against the cost of unnecessarily restricting their consumption. Using numerical optimisation techniques, we compare two innovative rules of thumb: (1) consuming the age-related percentage of remaining wealth specified in the Internal Revenue Service (IRS) Required Minimum Distribution (RMD) tables, and (2) consuming the age-related percentage of remaining wealth specified in the IRS RMD tables PLUS interest and dividends, with alternative rules of thumb and with the theoretical optimal. We show that in models that incorporate uncertain investment returns, the second RMD strategy (spending age-related percentages of remaining wealth PLUS interest and dividends) performs better than plausible alternatives, such as spending the interest and dividends, consuming an inflation-indexed 4 per cent of initial wealth, or decumulating over the household's life expectancy. Importantly, except for more risk-averse single males, it also performs better than the purchase of a market-load inflation-indexed annuity, and approaches the theoretical optimum.

The Geneva Papers (2013) 38, 729-752. doi:10.1057/gpp.2013.26

Keywords: asset decumulation; 401(k) pension wealth; required minimum distribution tables; annuitisation

Article submitted 06 February 2013; accepted 16 July 2013; published online October 2013

\section{Introduction}

Over the last 30 years, 401(k) and other defined contribution retirement plans have displaced defined benefit pension plans in the private sector. ${ }^{1}$ Defined benefit plans traditionally provided benefits in the form of a lifetime annuity. In contrast, in 401(k) plans, annuitisation is voluntary and rare. ${ }^{2}$ Participants face the challenge of decumulating their wealth over their remaining lifetimes, trading off the risk of outliving that wealth against the cost of unnecessarily restricting their consumption. $\mathrm{Yuh}^{3}$ suggests that close to half of all pre-retirees will be unable to maintain their standard of living in retirement.

Devising an optimal plan requires the application of numerical optimisation techniques that are beyond the abilities of households and their financial advisers. Households, to the

\footnotetext{
${ }^{1}$ For a discussion of trends in pension provision in the United States, see apRoberts (2009).

${ }^{2}$ In many plans it is not even an option, although households can still purchase annuities by rolling plan balances into IRAs and purchasing the annuity within the IRA.

${ }^{3}$ Yuh (2011).
} 
extent that they plan decumulation at all, must rely on rules of thumb that are clearly suboptimal. For example, a widely advocated rule is to consume an inflation-indexed 4 per cent of initial wealth. ${ }^{4}$ Bengen $^{5}$ shows that a household following this strategy is at relatively low risk of outliving its wealth. But optimality requires the household to smooth their consumption, equating the marginal utility of consumption this period with the expected marginal utility of next period's consumption multiplied by the 1-year survival probability, the rate of interest and the time discount factor. The 4 per cent rule is unlikely to equate marginal utilities, because the amount consumed neither responds to realised investment returns nor reflects the gradual decline in survival probabilities with age. ${ }^{6}$

Previous research has studied a variety of annuitisation and decumulation strategies-for example, comparing annuitising immediately at retirement with delayed annuitisation, and comparing a variety of drawdown algorithms. But the algorithms that have been investigated are not easy to follow, nor is there any evidence that households actually contemplate using them.

This paper explores an alternative approach, namely to compare two strategies based on published Internal Revenue Service (IRS) Required Minimum Distribution (RMD) tables with rules of thumb that households might plausibly consider following. These tables specify the minimum amounts that must be drawn out of IRA and 401(k) accounts to avoid tax penalties. Although the IRS makes no claim that the withdrawals are optimal, a strategy based on these tables does satisfy two important requirements of an optimal decumulation strategy. First, assuming no bequest motive, the percentage of remaining wealth that is consumed each year will increase with age, reflecting decreasing remaining life expectancy. Second, the dollar amount consumed will respond to fluctuations in the market values of financial assets.

Assuming plausible preference parameters, and using numerical optimisation techniques, we compare two strategies based on the RMD tables with three alternative rules of thumb and the purchase of an inflation-indexed annuity. ${ }^{7}$ The first RMD strategy involves consuming age-related percentages of remaining financial assets based on the RMD tables (the first RMD strategy hereafter). The second RMD strategy involves consuming these agerelated percentages PLUS interest and dividends (the second RMD strategy hereafter). To illustrate how the two RMD strategies would work, consider a 65-year-old couple whose financial assets total $\$ 100,000$. If it follows the first RMD strategy, at age 65, it consumes $\$ 3,130,3.13$ per cent of US $\$ 100,000$, the age 65 withdrawal percentage shown in Table 1 . If the interest and dividends on its investments total $\$ 2,000$, it spends $\$ 5,130$ following the second RMD strategy, 3.13 per cent of its $\$ 100,000$ capital, plus the $\$ 2,000$ interest and dividends. $^{8}$

4 A Google search for "four percent rule" and "retirement" produces over 50,000 hits.

5 Bengen (1994).

${ }^{6}$ Scott et al. (2009) and Milevsky and Huang (2011) document the 4 per cent rule's enduring popularity and explain why it is likely to be highly suboptimal.

${ }^{7}$ As discussed in footnote 33, we also found that the second RMD strategy dominated some more complex strategies evaluated in previous research.

${ }^{8}$ The household could, of course, do even better by consuming the amounts specified in the RMD tables, plus some assumed rate of interest, thus breaking the connection between the portfolio allocation and the drawdown rate. But our focus is on easy-to-follow strategies, and we deem the calculations required to execute this strategy to be too difficult. 
Table 1 Required minimum distribution tables

\begin{tabular}{lccc}
\hline Age & Percent & Age & Percent \\
\hline 65 & 3.13 & 83 & 6.13 \\
66 & 3.22 & 84 & 6.45 \\
67 & 3.31 & 85 & 6.76 \\
68 & 3.42 & 86 & 7.09 \\
69 & 3.53 & 87 & 7.46 \\
70 & 3.65 & 88 & 7.87 \\
71 & 3.77 & 89 & 8.33 \\
72 & 3.91 & 90 & 8.77 \\
73 & 4.05 & 91 & 9.26 \\
74 & 4.20 & 92 & 9.80 \\
75 & 4.37 & 93 & 10.42 \\
76 & 4.55 & 94 & 10.99 \\
77 & 95 & 11.63 \\
78 & 4.72 & 96 & 12.35 \\
79 & 4.93 & 97 & 13.16 \\
80 & 5.13 & 98 & 14.08 \\
81 & 5.35 & 99 & 14.93 \\
82 & 5.59 & 100 & 15.87 \\
\hline
\end{tabular}

Note: Authors' calculations based on Uniform Life Tables in Appendix C, Tables 2 and 3, Internal Revenue Service Publication 590, (2013).

The alternatives comprise: (1) spending the interest and dividends while preserving the capital; (2) the 4 per cent rule described above; (3) spending down over one's life expectancy and (4) purchasing an inflation-indexed annuity. We also calculate an optimal strategy and evaluate the RMD and alternative strategies in terms of "strategy equivalent wealth", the percentage by which the initial financial assets of a household following the RMD or other rule of thumb would have to be increased so that it was indifferent between the optimal strategy and the RMD or other rules of thumb. We test the sensitivity of our findings to alternative assumptions regarding rates of return, household wealth, marital status, risk preferences and annual mortality risk.

We first consider a model in which the household invests only in a single risk-free asset. We then extend the analysis to include a choice between risky stocks and a risk-free bond, assuming that the household adopts either an optimal or a typical portfolio allocation. Finally, we consider high and low mortality households.

We find that for almost all household types, the second RMD strategy performs substantially better than any of the alternatives and is close to optimal. This finding holds regardless of whether we assume a single risk-free asset, or an optimal or typical portfolio allocation including risky asset classes. The results are also robust to reasonable alternative assumptions about rates of return, household wealth, marital status, coefficients of riskaversion and mortality risk. Importantly, for most types of households, the second RMD strategy also outperforms the purchase of an inflation-indexed annuity.

The remainder of this paper is organised as follows. The second section presents a model of optimal wealth decumulation in retirement. The third section discusses how households appear to behave in practice, and critiques plausible rules of thumb. The fourth section describes the RMD tables. The fifth section compares both decumulation strategies based on 
the RMD tables, plausible alternatives and the purchase of an inflation-indexed annuity with the theoretical optimal, and tests the sensitivity of these results to alternative assumptions. The sixth section concludes.

\section{A model of optimal wealth decumulation in retirement}

Households managing wealth decumulation in retirement must trade off the risk of outliving their wealth against the cost of unnecessarily restricting their consumption. According to economic theory, they will choose a decumulation plan that maximises:

$$
E_{t} \sum_{t=65}^{T} B^{t-65}\left(\rho_{t}^{m} U_{m}+\rho_{t}^{f} U_{f}\right)
$$

This represents the sum of the husband's and wife's expected utilities from age 65 to terminal time $T$, an assumed maximum age of death of 100 , discounted by a time discount factor, $B$, which may vary between households, but is assumed to be 0.971 (1/1.03), and multiplied by $\rho_{t}^{m}$ and $\rho_{t}^{f}$ the probabilities that at time $t$, the husband and wife are still alive, conditional on being alive at the commencement of retirement.

We follow the decumulation literature ${ }^{9}$ and assume a constant relative risk aversion (CRRA) utility function of the following form:

$$
U_{m}\left(C_{t}^{m}, C_{t}^{f}\right)=\frac{\left(C_{t}^{m}, \lambda C_{t}^{f}\right)^{1-\gamma}}{1-\gamma}, U_{f}\left(C_{t}^{m}, C_{t}^{f}\right)=\frac{\left(C_{t}^{f}, \lambda C_{t}^{m}\right)^{1-\gamma}}{1-\gamma},
$$

where $\lambda$ equals the complementarity of consumption between husband and wife, assumed to be $0.5 .^{10}$ If both spouses are alive, they each consume half of the total household consumption. If only one spouse is alive, utility depends only on his or her consumption and he will no longer benefit from expense sharing, so the utility function simplifies to $C_{t}^{1-\gamma} / 1-\gamma$. We assume coefficients of risk aversion of 2 and $5 .^{11}$ Estimates in the academic literature range between 2 and 10, depending in part on whether the estimates are derived from portfolio theory, purchases of insurance, economic experiments or preferences over lotteries. ${ }^{12}$ We assume that the marginal utility of consumption does not vary with age. We follow the literature and do not incorporate health-care costs into our model. These costs increase with age. But their effect on optimal consumption is unclear as the marginal utility of non-health consumption may vary with health status.

\footnotetext{
${ }^{9}$ Brown and Poterba (2000); Horneff et al. (2008, 2010).

${ }^{10}$ An alternative would be to assume that basic living expenses, possibly an amount equal to Social Security benefits, did not contribute to utility. For a given coefficient of risk aversion, households would then choose a lower initial level of consumption and a less rapid decline in consumption with age.

${ }^{11}$ With CRRA utility, the coefficient of risk aversion also determines the intertemporal elasticity of substitution. Finke et al. (2012) show that the coefficient of risk aversion can have a dramatic effect on the optimal withdrawal rate, because low gamma households prefer greater consumption early in retirement when they are more likely to be alive.

12 Chetty (2003).
} 
In each period, households choose how much to consume, and how to allocate their wealth between stocks and bonds. The household's budget constraints are as follows:

$$
\begin{gathered}
C_{t}=d_{t} W_{t}+S S_{m s, t}-\tau_{t}, \\
W_{t+1}=W_{t}\left(1-d_{t}\right)\left(s_{t} r_{s}+b_{t} r_{b}+\left(1-s_{t}-b_{t}\right) r_{c}\right),
\end{gathered}
$$

where $C_{t}$ is total household consumption at time $t$. $W_{t}$ is household wealth at time $t . d_{t}$ is decumulation rate at time $t$. The value depends on the decumulation strategy chosen. $d_{t} W_{t}$ is household withdrawal from $401 \mathrm{k}$ account at time $t$. When the household purchases an inflation-indexed annuity, $W_{t}$ is always 0 and $d_{t} W_{t}$ is replaced by the annuity income. $S S_{m s, t}$ is Social Security benefits received by the household at time $t$, the amount of which depends on the marital status of the couple. $\tau_{t}$ is the federal income tax liability of the household at time $t$. It depends on marital status, Social Security income and 401(k) withdrawals. $s_{t}$ and $b_{t}$ are the percentages of wealth invested in stocks, and bonds at time $t$ respectively, and $r_{s}, r_{b}$, and $r_{c}$ are one plus the real returns on stocks, bonds, and cash, respectively. There is the usual nonnegativity constraint:

$$
W_{t} \geqslant 0 \text {. }
$$

To test the sensitivity of our results to alternative assumptions regarding asset returns and asset allocation, we first assume a single risk-free asset. We then assume that households optimally allocate their portfolio between stocks and bonds. We assume that real stock returns are log-normally distributed with a mean of 6.5 per cent and a standard deviation of 20.0 per cent, the average for the period $1926-2010 .^{13}$ The 6.5 per cent return includes dividends of 2.0 per cent, approximating to the current dividend yield on the S\&P500. ${ }^{14}$ One treatment of bonds would calculate the mean and standard deviation of historical returns and their covariance with stock returns. But Campbell and Viceira ${ }^{15}$ argue that this approach overstates the riskiness of bonds. In contrast to short-term deposits, which provide a guaranteed return of capital but an uncertain annual income, long-term bonds provide a guaranteed return on capital and a guaranteed return of capital on maturity. ${ }^{16}$ If a long-term investor knew his consumption requirements with certainty, he could fund them by buying a portfolio of bonds of appropriate maturities. We therefore assume that bonds yield a fixed real 3 per cent return, approximating to the average 2.76 per cent real interest rate on long-dated Treasury bonds over the period 1954-2010. ${ }^{17}$ Given our assumption regarding

\footnotetext{
13 Authors' calculations based on Ibbotson Associates (2010) data. If expected returns vary with market conditions, it would be optimal to adjust asset allocation based on whether equities or bonds were believed to offer returns that were higher or lower than the long-run average (Solow et al., 2011). It is computationally infeasible to solve a model incorporating time-varying returns using numerical optimisation techniques.

${ }^{14}$ We assume that the dividend yield is a constant 2 per cent. In reality, dividends fluctuate considerably less than stock prices, with the result that dividend yields tend to increase in bear markets and decrease in bull markets. Our model therefore understates the riskiness of the income stream from the second RMD strategy and correspondingly undervalues the attractiveness of the strategy.

${ }^{15}$ Campbell and Viceira (2002).

${ }^{16}$ Corporate bonds are subject to default risk. Government bonds and most short-term deposits are backed by government guarantees.

${ }^{17}$ Heiland and Yin (2013).
} 
the risk and return on long-dated bonds, our households are assumed to be unwilling to hold short-term deposits. We test the sensitivity of our results to the rate of return, considering an alternative in which the real risk-free rate is only 1 per cent and the expected real equity return only 4.5 per cent, respectively. Real interest rates are currently even lower. But we regard current conditions as quite exceptional and temporary, and hence prefer to evaluate the performance of the strategies under an assumption of more normal conditions.

Since short-term deposits constitute a substantial proportion of most households' portfolios, we also consider a model in which households hold typical portfolio allocations. Short-term nominal interest rates are currently close to zero and are substantially less than zero after deducting anticipated inflation, well below the historical average. ${ }^{18}$ To reflect both current and prospective short-term interest rates, we assume that short-term deposits yield a real 1 per cent return.

We consider single men, single women and married couples aged 65 . The household receives retired worker and spousal benefits from Social Security in the real amounts of $\$ 18,756$ and $\$ 9,378$ a year, respectively. ${ }^{19}$ In the event of the wife dying, spousal benefit ceases. In the event of the husband dying, the wife switches to the survivor benefit, also assumed to be $\$ 18,756$ a year. We assume that the household has $\$ 250,000$ of financial assets, slightly below the $80^{\text {th }}$ percentile of the distribution of financial assets among retired Health and Retirement Study (HRS) households entering retirement, but also test the sensitivity of our findings to alternative assumed wealth levels. ${ }^{20}$ Under the assumption of CRRA, households with smaller amounts of financial wealth relative to their Social Security wealth will prefer a faster decumulation of financial assets. But the maintenance of liquidity may be an important consideration for households with modest amounts of financial assets, and we therefore do not attempt to test the sensitivity of our findings to assumed wealth levels of under $\$ 100,000$. Likewise, we do not analyse the most affluent, for whom bequests may be an important consideration. ${ }^{21}$

${ }^{18}$ Historical averages are potentially misleading, reflecting the inflation shocks of the 1970s and 1980s. Survey of Professional Forecasters data on the 1-year anticipated rate of inflation is available only from 1981. We estimate inflation expectations for the period 1960-1981 using a time series model. Using the above data, we calculate that the anticipated real interest rate on 1-year Treasury bills averaged just over 2 per cent during the period 1960-2011.

${ }^{19}$ In 2009, the average Primary Insurance Amount (PIA) for new retired worker benefit awards to men was \$1,563 ( $\$ 18,756$ a year). The $80^{\text {th }}$ percentile of retired worker benefits is $\$ 2,075$ (Social Security Administration, 2010, Table 6.B4). Workers typically retire before their Full Retirement Age and receive less than their PIA. There is a less than perfect correlation between financial assets and Social Security benefits, so a worker at the $80^{\text {th }}$ percentile of the distribution of financial assets will be at less than the $80^{\text {th }}$ percentile of the distribution of retired worker benefits. Taking the above into account, we regard $\$ 1,563$ as a reasonable approximation to the benefits someone at the $80^{\text {th }}$ percentile of the wealth distribution might actually receive. The results assuming $\$ 2,075$ are available from the authors and are not significantly different. Social Security benefits are indexed to the Consumer Price Index

${ }^{20}$ The Health and Retirement Study is a nationally representative sample of older Americans. Our calculations are based on 2008 data. Median financial assets of household approaching retirement are close to zero and unlikely to contribute significantly to post-retirement consumption.

${ }^{21}$ The literature suggests that over most of the wealth distribution, households have a negligible bequest motive (e.g. Hurd, 2002). These households may leave a bequest, but this reflects uncertainty as to the time of death, and they will not reduce current consumption in order to increase the amount of that bequest. Households with a bequest motive could modify the RMD strategy by applying it to their wealth, exclusive of the amount they 
We ignore housing equity. ${ }^{22}$ We model the federal income tax, and in particular, its treatment of Social Security income, and assume that all financial wealth is held in tax-deferred accounts. ${ }^{23} \mathrm{We}$ also investigate the sensitivity of our results to alternative assumptions regarding mortality rates.

\section{How do households behave and why do rules of thumb fall short?}

Many elderly households retain large amounts of wealth until advanced old age. Hurd and Rohwedder (2013) find evidence of decumulation by elderly singles, but find limited evidence for couples, possibly reflecting a desire to preserve wealth for the surviving spouse. De Nardi et $a l .{ }^{24}$ find that elderly single women decumulate their financial assets very slowly and attribute this to the risk of uninsured medical costs.

It is unclear what decision rules households adopt. $\mathrm{Webb}^{25}$ analyses a variety of plausible rules of thumb. One strategy is to spend the interest and dividends, while preserving the capital. This strategy has a number of serious drawbacks. First, the amount bequeathed, its initial wealth plus capital gains unconsumed, may not accord with the strength of its bequest motive. Second, both initial consumption and the rate of growth of consumption will depend on asset allocation and may not accord with the household's preferences. The dividend yield on the S\&P 500 stock market index is approximately 2 per cent, far less than the interest return on an investment in nominal bonds. So households that invest in stocks will have lower initial income than those that invest in bonds. Third, the household may allow its need for income to dictate its portfolio allocation, arriving at a portfolio that suboptimally trades off risk against return, whereas if the household is freed from the constraints of this rule, it can jointly determine an optimal portfolio allocation and an optimal drawdown strategy.

A second strategy is to spend 4 per cent of wealth at retirement in each year, increasing the amount spent in line with inflation. Bengen ${ }^{5}$ calculated that a household adopting this strategy faced only a small probability of outliving its wealth. This strategy is suboptimal, because it does not respond to realised asset returns. If asset returns are higher than expected, the household can and should respond by increasing consumption. If, conversely, the household is on track to exhaust its wealth in a few years, it should reduce current consumption and not delay until its financial assets are exhausted. The strategy also fails to reflect the

wish to pass as a bequest, consuming only the interest and dividends on the intended bequest. Households that wanted to leave all their wealth as a bequest would, of course, have no need of a decumulation strategy.

${ }^{22}$ Venti and Wise (2004) show that households typically do not consume housing equity until advanced old age. We acknowledge that some households may retain housing equity as self-insurance against medical and longterm care costs (Davidoff, 2010).

${ }^{23}$ Only the wealthy hold significant amounts of financial assets outside of their retirement savings accounts. The taxation treatment of Social Security benefits is as follows: First, the household's "combined income" is calculated. This equals regular taxable income plus 50 per cent of Social Security income. The amount of Social Security income that is taxable is the minimum of three tests: (1) 50 per cent of combined income over the first threshold ( $\$ 25,000$ for singles and $\$ 32,000$ for married couples), plus 35 per cent of combined income over the second threshold ( $\$ 34,000$ for singles and $\$ 44,000$ for married couples); (2) 50 per cent of benefits plus 85 per cent of combined income over the second threshold; (3) 85 per cent of benefits (Internal Revenue Service, 2012). These limits are fixed in nominal terms.

${ }^{24}$ De Nardi et al. (2010).

25 Webb (2009). 
prediction of the life cycle model that households should, at least to some extent, prefer higher consumption early in retirement when they are more likely to be alive to enjoy it. ${ }^{26}$

A third strategy is to spend down over one's life expectancy or to an age at which there is a low probability of surviving. The variant of this strategy that we model is to consume a fraction of initial wealth equal to:

$$
\frac{r}{1-(1+r)^{-t}}
$$

in each period, where $r$ is the risk-free interest rate, and $t$ is life expectancy at retirement (23.5 years for couples turning 65 in 2012, 27.4 years where the wife is 6 years younger, and 16.7 and 19.7 years for single men and women, respectively). ${ }^{27}$ This is clearly suboptimal in that the household fails to smooth its consumption. In the period in which financial assets are exhausted, consumption drops to the amount of the household's Social Security benefits.

Elderly households also invest their financial assets very conservatively, holding large percentages of their wealth in short-term deposits. ${ }^{28}$ Although this strategy guarantees a return on capital, it does not guarantee what is arguably of greater importance, the rate of return on capital. It also means that households earn very low real returns on their portfolios. In our calculations, we first assume that households jointly choose an optimal portfolio allocation and drawdown rate. Recognising that our optimal asset allocation differs substantially from typical asset allocations adopted by older households, we consider an alternative in which households adopt the average portfolio allocation of households aged over 65 and between the $60^{\text {th }}$ and $80^{\text {th }}$ percentiles of the distribution of financial assets and then choose an optimal drawdown rate, given that asset allocation. When considering this alternative, we are implicitly assuming that our decumulation model does not omit some aspect of risk preferences that would, in fact, make the observed investment allocation optimal. For example, it is possible that households are much more risk-averse than commonly assumed, and that typical portfolio allocations are consistent with true levels of risk-aversion.

\section{What are the RMD tables?}

An individual who has attained age $70 \frac{1}{2}$ during the calendar year and has assets in an IRA or $401(\mathrm{k})$ is required to make a minimum withdrawal of a specified percentage of the account balance on the previous 31 December. Individuals who fail to make the withdrawals are subject to a tax penalty of 50 per cent of the amount they failed to withdraw. The rules do not apply to Roth IRA account balances while the owner is alive.

Single account holders and married account holders who are less than 10 years older than their spouse are required to use the Uniform Life Table in Appendix X, Table 3 of IRS publication 590. This table specifies "distribution periods" that vary with age, decreasing

\footnotetext{
${ }^{26}$ In some circumstances, the household may prefer level or even increasing consumption, for example, if increases in health costs increase the marginal utility of consumption at older ages, if the intertemporal elasticity of consumption is very low, if the rate of time preference is less than the rate of interest, or if the household engages in "precautionary saving" in the face of uncertain investment returns.

${ }^{27}$ In this birth cohort, wives are, on average, 3 years younger than their husbands.

${ }^{28}$ Coile and Milligan (2009).
} 
Table 2 Alternative strategy equivalent wealth-No investment risk

\begin{tabular}{|c|c|c|c|c|c|c|}
\hline \multirow[t]{2}{*}{ Scenario } & \multicolumn{6}{|c|}{ Alternative to optimal drawdown } \\
\hline & $\begin{array}{l}\text { RMD } \\
\text { tables }\end{array}$ & $\begin{array}{c}R M D \\
\text { tables }+ \text { spend } \\
\text { interest }\end{array}$ & $\begin{array}{l}\text { Spend } \\
\text { interest }\end{array}$ & $4 \%$ rule & $\begin{array}{c}\text { Spend over } \\
\text { life-expectancy }\end{array}$ & $\begin{array}{c}\text { Inflation-indexed } \\
\text { annuity }\end{array}$ \\
\hline \multicolumn{7}{|c|}{3 per cent interest rate } \\
\hline \multicolumn{7}{|c|}{ Married couples } \\
\hline \multicolumn{7}{|l|}{ Same age } \\
\hline $\mathrm{CRRA}=2$ & 1.343 & 1.032 & 1.232 & 1.307 & 1.039 & 1.105 \\
\hline $\mathrm{CRRA}=5$ & 1.279 & 1.110 & 1.176 & 1.218 & 1.582 & 1.039 \\
\hline \multicolumn{7}{|c|}{ Wife 6 years younger } \\
\hline $\mathrm{CRRA}=2$ & 1.266 & 1.031 & 1.178 & 1.215 & 1.043 & 1.126 \\
\hline $\mathrm{CRRA}=5$ & 1.206 & 1.170 & 1.135 & 1.145 & 1.368 & 1.064 \\
\hline \multicolumn{7}{|l|}{ Single men } \\
\hline $\mathrm{CRRA}=2$ & 1.410 & 1.042 & 1.259 & 1.355 & 1.169 & 0.908 \\
\hline $\mathrm{CRRA}=5$ & 1.312 & 1.118 & 1.186 & 1.236 & NA & 0.827 \\
\hline \multicolumn{7}{|l|}{ Single women } \\
\hline $\mathrm{CRRA}=2$ & 1.295 & 1.041 & 1.211 & 1.265 & 1.107 & 0.958 \\
\hline $\mathrm{CRRA}=5$ & 1.237 & 1.188 & 1.175 & 1.182 & NA & 0.895 \\
\hline \multicolumn{7}{|c|}{1 per cent interest rate } \\
\hline \multicolumn{7}{|c|}{ Married couples } \\
\hline \multicolumn{7}{|l|}{ Same age } \\
\hline $\mathrm{CRRA}=2$ & 1.381 & 1.077 & 1.635 & 1.163 & 1.076 & 0.945 \\
\hline $\mathrm{CRRA}=5$ & 1.227 & 1.048 & 1.478 & 1.105 & 1.258 & 0.844 \\
\hline \multicolumn{7}{|c|}{ Wife 6 years younger } \\
\hline $\mathrm{CRRA}=2$ & 1.313 & 1.056 & 1.534 & 1.113 & 1.097 & 0.947 \\
\hline $\mathrm{CRRA}=5$ & 1.167 & 1.059 & 1.389 & 1.145 & 1.183 & 0.843 \\
\hline \multicolumn{7}{|l|}{ Single men } \\
\hline $\mathrm{CRRA}=2$ & 1.438 & 1.094 & 1.682 & 1.196 & 1.100 & 0.776 \\
\hline $\mathrm{CRRA}=5$ & 1.263 & 1.061 & 1.509 & 1.101 & NA & 0.678 \\
\hline \multicolumn{7}{|l|}{ Single women } \\
\hline $\mathrm{CRRA}=2$ & 1.324 & 1.062 & 1.584 & 1.118 & 1.068 & 0.806 \\
\hline $\mathrm{CRRA}=5$ & 1.188 & 1.074 & 1.455 & 1.100 & NA & 0.719 \\
\hline
\end{tabular}

Notes: We assume population average mortality for the 1946 birth cohort. For the scenario in which the wife is six years younger than the husband, we assume the account is in the husband's name, and that the wife has population average mortality for the 1952 birth cohort. It is assumed that the husband's Social Security Primary Insurance Amount is $\$ 1,000$, and that the wife is only entitled to a $\$ 500$ spousal benefit per month. The household has $\$ 250,000$ in financial assets, the $70^{\text {th }}$ percentile of the distribution of financial wealth for Health and Retirement Study households aged 60-69 in 2008.

from 27.4 years at 70 to 18.7 at $80,11.4$ at 90 and 6.3 at 100 . The percentage withdrawal equals 100 divided by the distribution period, so the required minimums at the above ages are $3.65,5.35,8.77$ and 15.9 per cent.

Since this requirement applies only to individuals who have attained age $701 / 2$, the IRS does not publish distribution periods for younger ages. But these can be derived from Table 2 in the same publication. ${ }^{29}$ Distribution periods for ages $65-100$, calculated in accordance with the IRS methodology, are reported in Table 1 of this paper.

The distribution periods are the IRS's estimates of the joint life expectancies of couples in which the spouse is 10 years younger than the account holder, calculated using life tables that do not distinguish between male and female mortality. ${ }^{30}$ (They differ somewhat from life

\footnotetext{
29 They are the Table 2 values for spouses exactly 10 years younger than the account holder.

${ }^{30}$ The joint life expectancy is the average number of years that one or both spouses will be alive.
} 
expectancies calculated using Social Security Administration (SSA) cohort life tables.) According to the IRS, the joint life expectancy of a couple in which one spouse is $70^{1 / 2}$ and the other spouse is up to 10 years younger is 27.4 years. Using SSA life tables, we calculate the life expectancy of a couple with population average mortality in which the husband and wife are both $70^{1 / 2}$ in 2011 to be 19.9 years. If the wife is 10 years younger, it is 26.3 years, and for the typical household in which the wife is 3 years younger than the husband, it is 21.5 years.

The IRS makes no claim that a decumulation strategy based on the RMD tables is optimal for all or any households. Further, although the IRS requires individuals to make withdrawals, households are not required to spend them. The purpose of the legislation is to recover the tax relief granted when the contribution was made and to ensure that taxadvantaged savings are used to fund retirement, rather than to fund a bequest. But the strategy does possess two important characteristics of an optimal strategy. First, the withdrawal rate is expressed as a percentage of remaining wealth. As a result, the dollar amount consumed responds to market returns. Second, the percentage withdrawal rate increases with age, reflecting the age-related decline in remaining life expectancy.

\section{Comparing the RMD strategies with alternatives}

For typical households age 65, we first calculate an optimal decumulation and asset allocation strategy, given risk preferences, annual mortality risk, financial wealth, Social Security income, marital status and age difference between husband and wife. We calculate expected lifetime utility. We then assume that the household either adopts one of the two decumulation strategies based on the RMD tables described in the introduction, follows one of the rules of thumb strategies described in Section "How do households behave and why do rules of thumb fall short?", or purchases an inflation-indexed annuity. The annuity is assumed to have a money's worth of 79.2 per cent of the premium paid. ${ }^{31}$ The annuity income from $\$ 1$ invested in an inflation-indexed annuity can be calculated using the following equation:

$$
A=\frac{\theta}{\sum_{t=65}^{T} R^{65-t}\left[\rho_{t}^{m} \rho_{t}^{f}+\delta\left(\rho_{t}^{m}\left(1-\rho_{t}^{f}\right)+\left(1-\rho_{t}^{m}\right) \rho_{t}^{f}\right)\right]},
$$

where $A$ is the annual annuity payment when both spouses are alive. $\delta A$ is the payment when only one spouse is alive. Following literature and common practice, $\delta$ is set at $2 / 3$. $\theta$ is the market load of 79.2 per cent as mentioned above. $R$ is one plus the real rate of interest, the $\rho_{t}^{m}$ and $\rho_{t}^{f}$ are the probabilities of a male and female surviving to time $t$, conditional on being alive at retirement. Households are not permitted to change strategy after retirement.

\footnotetext{
31 The Mitchell et al. (1999) money's worth estimate assumes population mortality and corporate bond interest rates. We assume population mortality for the 1946 birth cohort (1952 for the wife, when she is 6 years younger), as specified in Social Security Administration life tables. We ignore aggregate mortality risk, the possibility that the tables might turn out to be incorrect. Although aggregate mortality risk is a substantial risk for insurance companies selling annuities, for households, it is dominated by idiosyncratic risk.
} 
We calculate strategy equivalent wealth (SEW), the factor by which age-65 pension wealth must be multiplied so that the household is indifferent between adopting the optimal strategy and the alternative. By construction, SEW for the rules of thumb can never be less than one. ${ }^{32}$ A more suboptimal strategy will have higher SEW. SEW therefore provides a utility-based means of comparing the RMD strategies with both the optimal strategy, plausible rules of thumb and the purchase of an annuity.

Table 2 reports results for the base case in which the household invests an initial $\$ 250,000$ in a risk-free asset. The first two columns show SEW for the two RMD strategies, the third to fifth columns show SEW for the strategies of spending the interest, following the 4 per cent rule, and spending down over one's life expectancy, and the sixth column assumes that the household purchases an inflation-indexed annuity. ${ }^{33}$

The upper panel assumes a risk-free rate of 3 per cent, commonly assumed in the decumulation literature. ${ }^{34}$ Current yields on long-dated Treasury Inflation Protected Securities are less than zero. But these rates reflect the effects of quite exceptional monetary policy. In the lower panel we therefore report results assuming a low interest-rate scenario of a 1 per cent real interest rate. For the "spend the interest" strategy, we assume in both panels that wealth is invested in long-dated corporate bonds yielding a nominal return of 5.5 or 3.5 per cent, corresponding to real returns of 3 per cent and 1 per cent, at an assumed 2.5 per cent inflation rate. ${ }^{35}$ The household spends the 5.5 or 3.5 per cent interest payments, and allows the real value of its investment to be eroded by inflation. The annuity income reflects the assumed interest rate. For the low interest-rate calculations, we retain our assumption of a 2 per cent dividend yield, but reduce expected capital appreciation on stocks from 4.5 per cent (6.5 per cent total return minus 2 per cent dividend yield) to 2.5 per cent (4.5 per cent total return minus 2 per cent dividend yield).

At a 3 per cent real interest rate, the strategies of spending the interest and following the 4 per cent rule both perform substantially worse than the optimal strategy. This is because they both result in less than optimal consumption early in retirement. Households have a preference for greater consumption early in retirement when they are more likely to be alive to enjoy it. In contrast, the strategy of consuming over one's life expectancy is suboptimal, because the household consumes too much early in retirement and too little after its financial wealth is exhausted. The first RMD strategy is also substantially worse than the optimal, because it also results in too little being consumed early in retirement. But this deficiency is remedied if the second RMD strategy is followed. The second RMD strategy is not only almost invariably

${ }^{32}$ SEW for the inflation-indexed annuity can sometimes be less than one, because annuitisation can dominate an optimal drawdown of unannuitised wealth.

${ }^{33}$ Authors have proposed additional rules of thumb to those studied in this paper. For example, Dus et al. (2005) consider strategies of consuming a constant fraction of remaining wealth, and consuming $1 / T$ where $T$ is the maximum possible remaining years of life. We find that the second RMD strategy usually substantially outperforms these strategies. We report selected results in Tables A1, A2 and A3. Variable payout immediate annuities offer households the benefits of both longevity insurance and the equity premium and are, in theory, attractive (Horneff et al., 2010). But sales have been even more limited than those of fixed immediate annuities, and we therefore exclude them from our analysis. Yet another approach is to delay annuitisation (Dushi and Webb, 2004; Horneff et al., 2008). We do not include delayed annuitisation as an option, because there are substantial costs to mis-timing the purchase and our focus is on simple rules of thumb.

${ }^{34}$ E.g. Mitchell et al. (1999).

35 As of 30 December 2011, the nominal yield on high-grade corporate bonds was 4.68 per cent. 


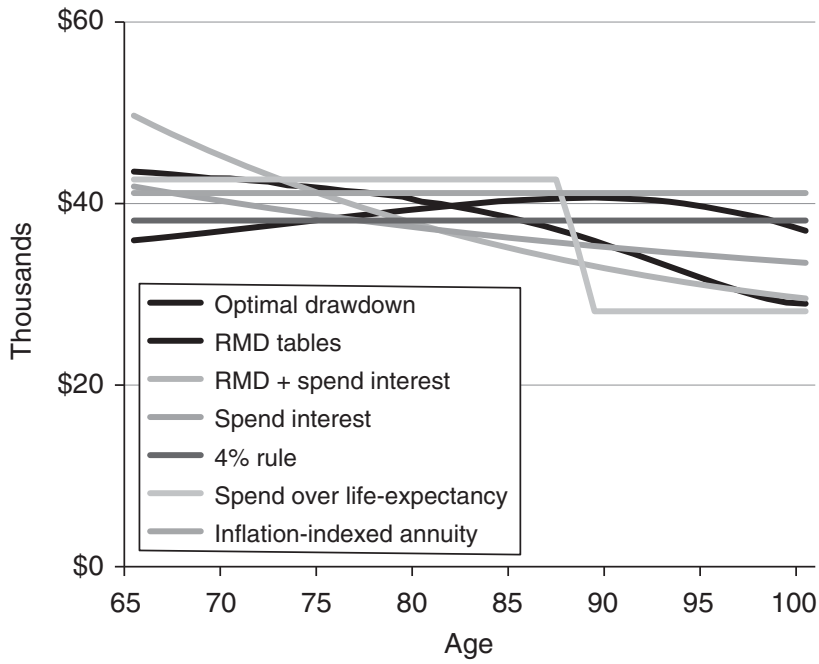

Figure 1. Consumption path of alternative decumulation strategies-No investment risk.

much superior to the rules of thumb, but also very close to optimal for all household types and at both assumed coefficients of risk-aversion. Importantly, the second RMD strategy performs as well as, and sometimes better than, the strategy of purchasing an inflation-indexed annuity. This is because the household values the opportunity to participate in the equity risk premium, given that it is insured against very low consumption by Social Security.

The cost of following the strategy of spending down over one's life expectancy can be highly sensitive to the assumed coefficient of risk-aversion and the proportion of wealth that is pre-annuitised. At a low coefficient of risk-aversion/high intertemporal elasticity of substitution, the household is relatively sanguine about the risk of surviving long enough to exhaust its financial assets. At a high coefficient of risk aversion, the household can be highly averse to this risk, resulting in a very high SEW. In our example, assuming a 3 per cent interest rate and assuming that both husband and wife are the same age, increasing the coefficient of risk aversion from 2 to 5 is associated with an increase in SEW from 1.035 to 1.153. But for single men and women, SEW is infinitely large at a coefficient of risk aversion of 5 , reflecting the lower assumed proportion of pre-annuitised wealth.

Figure 1 shows consumption for ages 65 to 100 for each of the above strategies for an intact married couple, both the same age and assuming a coefficient of risk aversion of 5 and a real interest rate of 3 per cent. The optimal strategy yields declining consumption, reflecting the reduced probabilities of being alive at older ages. The strategy of spending the interest and dividends results in consumption that is too low until after age 91. A household that adheres to the 4 per cent rule never outlives its wealth, but also consumes suboptimally until age 86 , while a household that spends down over its life expectancy exhausts its wealth by age 88 . The first RMD strategy is clearly suboptimal, because consumption increases with age, peaking at 89 . The second RMD strategy results in a consumption stream that is somewhat too high at younger ages, and somewhat too low after age 74 .

Figure 2 shows how wealth evolves under the various decumulation strategies. All except the second RMD strategy and the strategy of spending down over one's life expectancy 


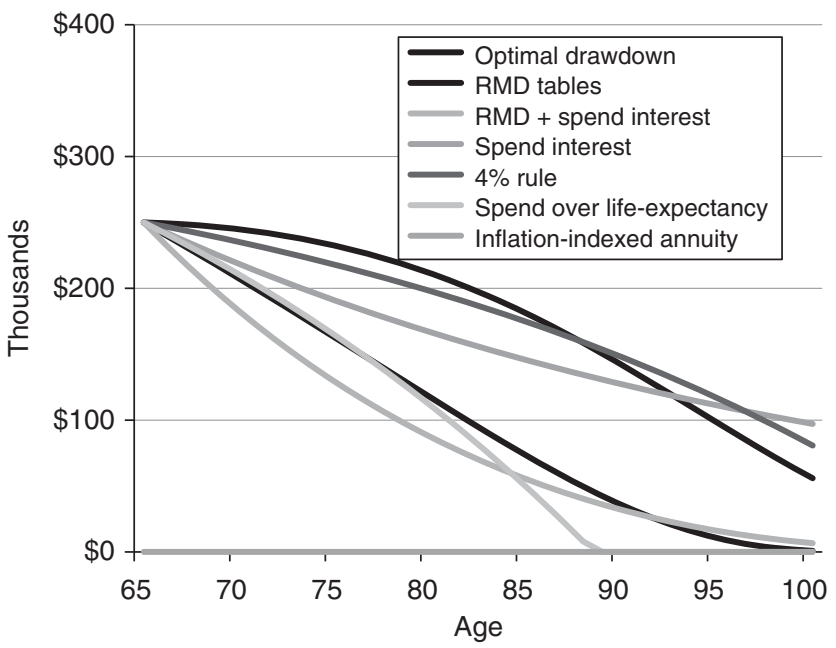

Figure 2. Wealth path of alternative decumulation strategies-No investment risk.

result in wealth being decumulated at a slower than optimal rate. The strategy of spending down over one's life expectancy is fairly close to optimal until about age 80. From that age onwards, remaining wealth is decumulated much too rapidly.

Lower interest rates have income and substitution effects on the optimal consumption path, with households both reducing consumption and shifting consumption to earlier in retirement. At lower coefficients of risk aversion, the latter effect is relatively more important. So when $\gamma=2$, a reduction in interest rates leaves optimal age 65 consumption unchanged but results in substantial reductions in consumption at older ages. When $\gamma=5$, optimal consumption decreases at all ages.

At lower interest rates, the second RMD strategy is again close to optimal. It again dominates the three rules of thumb, but no longer dominates the purchase of an inflationindexed annuity. At low interest rates, the strategy of spending the interest is highly suboptimal at both assumed coefficients of risk aversion, because it results in levels of consumption that are far below the optimal. But the 4 per cent rule is less suboptimal, even though, at the lower interest rate, there is now a small probability of the household outliving its wealth, because consumption under the 4 per cent rule is closer to the now reduced optimal level.

In results that are not reported, we find that all the rules of thumb are more suboptimal for households with the same Social Security benefits, but only $\$ 100,000$ of financial wealth. They are somewhat less suboptimal when we assume the same benefits but $\$ 500,000$ of financial wealth. These results follow from our preference assumptions. When the household has less financial wealth, the expected present value of Social Security benefits occupies a larger part of the household's extended portfolio. Under the assumption of CRRA utility, the household's optimal plan requires a more rapid decumulation of financial assets. But at both these wealth levels, the second RMD strategy dominates the alternatives for most of our household types. 
Table 3 Alternative strategy equivalent wealth-Optimal portfolio allocation

\begin{tabular}{|c|c|c|c|c|c|c|}
\hline \multirow[t]{2}{*}{ Scenario } & \multicolumn{6}{|c|}{ Alternative to optimal drawdown } \\
\hline & $\begin{array}{l}R M D \\
\text { tables }\end{array}$ & $\begin{array}{c}R M D \\
\text { tables }+ \text { spend } \\
\text { interest }\end{array}$ & $\begin{array}{c}\text { Spend } \\
\text { interest }\end{array}$ & $4 \%$ rule & $\begin{array}{c}\text { Spend over } \\
\text { life-expectancy }\end{array}$ & $\begin{array}{c}\text { Inflation-indexed } \\
\text { annuity }\end{array}$ \\
\hline \multicolumn{7}{|l|}{ Base case } \\
\hline \multicolumn{7}{|l|}{ Married couples } \\
\hline \multicolumn{7}{|l|}{ Same age } \\
\hline $\mathrm{CRRA}=2$ & 1.370 & 1.105 & 1.590 & 1.778 & 1.297 & 1.498 \\
\hline $\mathrm{CRRA}=5$ & 1.393 & 1.033 & 1.361 & 1.485 & 1.289 & 1.258 \\
\hline \multicolumn{7}{|c|}{ Wife 6 years younger } \\
\hline $\mathrm{CRRA}=2$ & 1.291 & 1.071 & 1.533 & 1.717 & 1.365 & 1.585 \\
\hline $\mathrm{CRRA}=5$ & 1.316 & 1.023 & 1.312 & 1.423 & 1.272 & 1.319 \\
\hline \multicolumn{7}{|l|}{ Single men } \\
\hline $\mathrm{CRRA}=2$ & 1.442 & 1.126 & 1.598 & 1.783 & 1.232 & 1.194 \\
\hline $\mathrm{CRRA}=5$ & 1.417 & 1.035 & 1.350 & 1.473 & NA & 0.986 \\
\hline \multicolumn{7}{|l|}{ Single women } \\
\hline CRRA $=2$ & 1.329 & 1.085 & 1.551 & 1.728 & 1.243 & 1.309 \\
\hline $\mathrm{CRRA}=5$ & 1.333 & 1.029 & 1.320 & 1.427 & NA & 1.080 \\
\hline \multirow{2}{*}{\multicolumn{7}{|c|}{ Bonds and expected stock returns reduced by 2 percentage points }} \\
\hline & \multicolumn{6}{|c|}{ Married couples } \\
\hline \multicolumn{7}{|l|}{ Same age } \\
\hline $\mathrm{CRRA}=2$ & 1.367 & 1.123 & 2.068 & 1.539 & 1.352 & 1.275 \\
\hline CRRA $=5$ & 1.316 & 1.056 & 1.753 & 1.297 & 1.252 & 1.054 \\
\hline \multicolumn{7}{|c|}{ Wife 6 years younger } \\
\hline $\mathrm{CRRA}=2$ & 1.288 & 1.083 & 1.951 & 1.482 & 1.440 & 1.326 \\
\hline $\mathrm{CRRA}=5$ & 1.245 & 1.037 & 1.661 & 1.281 & 1.271 & 1.087 \\
\hline \multicolumn{7}{|l|}{ Single men } \\
\hline $\mathrm{CRRA}=2$ & 1.439 & 1.157 & 2.102 & 1.548 & 1.193 & 1.024 \\
\hline $\mathrm{CRRA}=5$ & 1.343 & 1.064 & 1.743 & 1.277 & NA & 0.820 \\
\hline \multicolumn{7}{|l|}{ Single women } \\
\hline $\mathrm{CRRA}=2$ & 1.324 & 1.100 & 1.998 & 1.484 & 1.231 & 1.102 \\
\hline $\mathrm{CRRA}=5$ & 1.263 & 1.046 & 1.682 & 1.249 & NA & 0.884 \\
\hline
\end{tabular}

Notes: We assume population average mortality for the 1946 birth cohort. For the scenario in which the wife is six years younger than the husband, we assume the account is in the husband's name, and that the wife has population average mortality for the 1952 birth cohort. It is assumed that the husband's Social Security Primary Insurance Amount is $\$ 1,000$, and that the wife is only entitled to a $\$ 500$ spousal benefit per month. The household has $\$ 250,000$ in financial assets, the $70^{\text {th }}$ percentile of the distribution of financial wealth for Health and Retirement Study households aged 60-69 in 2008. The household adopts an optimal allocation of financial assets between stocks and risk-free bonds.

Table 3 reports results for models in which the household chooses an optimal portfolio allocation between stocks and bonds. The upper panel reports results when we assume mean real stock returns of 6.5 per cent and real bond returns of 3 per cent. The bottom panel reports results when we reduce the nominal bond coupon and expected stock capital gains by 2 percentage points, retaining the assumption of a 2 per cent dividend yield. At both coefficients of risk aversion, and at both assumed rates of return, the second RMD strategy dominates all three rules of thumb. For all household types except single males with the higher assumed coefficient of risk aversion of 5, the second RMD strategy also dominates the purchase of an inflation-indexed annuity. The strategy of spending the interest, again, performs worse at lower assumed interest rates because, at lower interest rates, the household substantially reduces consumption.

Figure 3(a) shows average consumption from age 65 to age 100 for in-tact married couples based on 10,000 Monte Carlo simulations, assuming a coefficient of risk aversion of 5 and 
Wei Sun and Anthony Webb RMD Tables-A Better Asset Decumulation Strategy
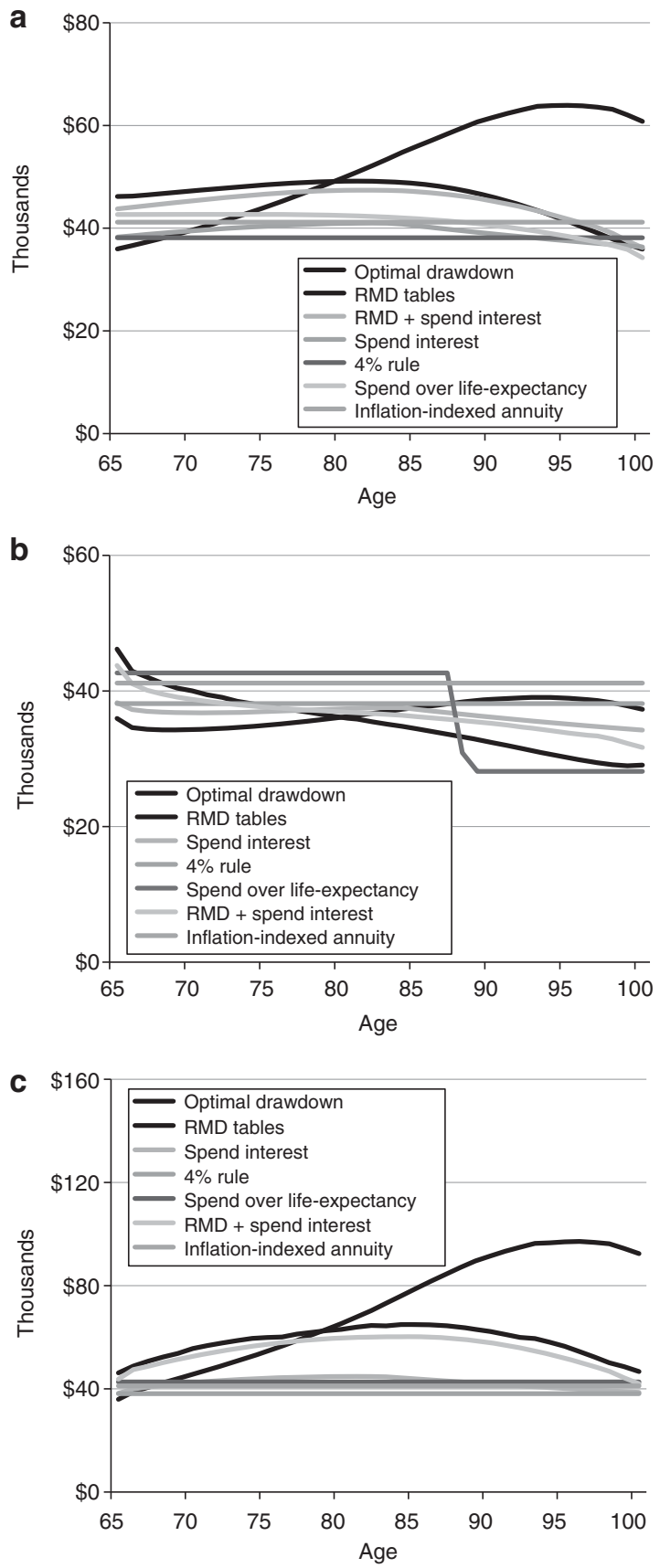

Figure 3. Consumption path of alternative decumulation strategies-Optimal portfolio allocation: (a) Mean; (b) $10^{\text {th }}$ percentile; (c) $90^{\text {th }}$ percentile. 


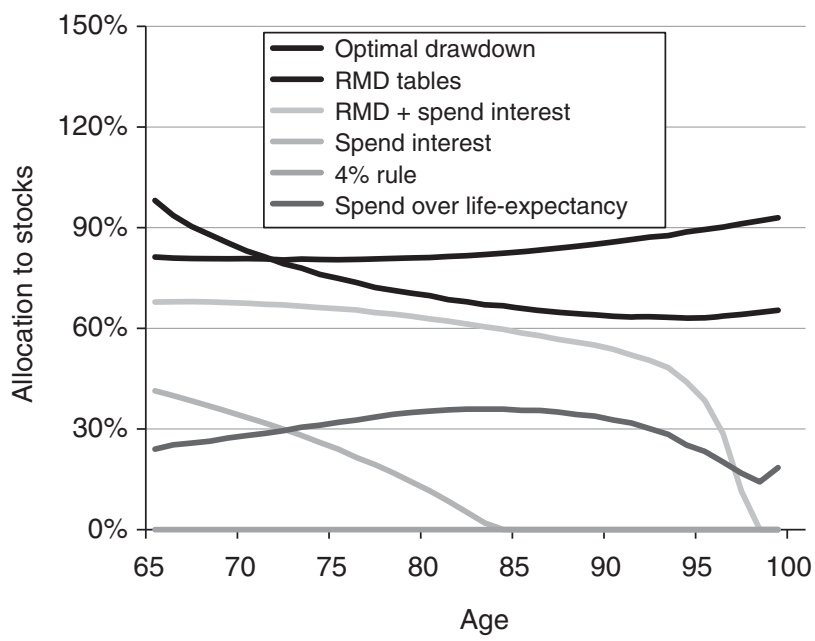

Figure 4. Optimal portfolio allocation of alternative decumulation strategies-Mean.

stock and bond returns of 6.5 and 3 per cent, respectively. In contrast to Figure 1, which assumed a risk-free rate of return, households optimally choose a consumption plan that, on average, results in increasing consumption early in retirement, reflecting both precautionary saving and the substitution effect resulting from higher expected returns. The second RMD strategy is almost identical to the optimal at almost all ages, but the first RMD strategy results in too little consumption at younger ages. The 4 per cent rule results in a level consumption path that is lower than that obtainable with an inflation-indexed annuity. Households following the 4 per cent rule are not permitted to increase their consumption should they enjoy higher than expected returns. Their spending is sufficiently low for them to be certain of not outliving their wealth if they only invest in bonds. They therefore have no incentive to invest in stocks. In contrast, households that spend down over their life expectancy have somewhat higher consumption and run the risk of outliving their wealth even if they invest in bonds. They therefore invest in a mixed stock-bond portfolio. The age-related decline in the consumption of households spending down over their life expectancy reflects an age-related increase in the percentages of households who have outlived their wealth.

Figure $3(\mathrm{a})$ and (b) show the $10^{\text {th }}$ and $90^{\text {th }}$ percentiles of the consumption paths, respectively. At both these percentiles, consumption under the second RMD strategy is closest to the optimal. The 4 per cent rule yields higher consumption than the second RMD strategy at the $10^{\text {th }}$ percentile, because households following this rule have optimally chosen an allbond portfolio.

Figure 4 shows portfolio allocations to equities for in-tact married couples based on 10,000 Monte Carlo simulations, again assuming a coefficient of risk aversion of 5 and a bond return of 3 per cent. ${ }^{36}$ For households consuming the optimal percentage of wealth each period, the optimal stock allocation increases with age, from 81 per cent at age 65 to 93 per

\footnotetext{
${ }^{36}$ Households purchasing an inflation-indexed annuity have no remaining wealth and therefore no portfolio allocation to be analysed.
} 
cent at age 99. This reflects the age-related decrease in financial wealth as a percentage of the expected present value of remaining lifetime Social Security benefits. Although the second RMD strategy is close to optimal, its associated portfolio allocation is far from optimal. This is because households invest larger proportions of their portfolio in bonds to boost current income. Households adopting a strategy of spending the interest invest relatively small proportions of their wealth in stocks, in order to earn higher income returns on bonds. As explained in the previous paragraph, households following the 4 per cent rule optimally allocate 0 per cent of their financial assets to stocks. Households spending down over their life expectancy invest smaller proportions of their wealth in stocks than under the optimal strategy. These results illustrate how choosing a rule of thumb drawdown strategy can distort the household's investment allocation decision. ${ }^{37}$

Figure 5(a), (b) and (c) show the mean, $10^{\text {th }}$ and $90^{\text {th }}$ percentile of the wealth paths, respectively, for in-tact married couples, again based on 10,000 Monte Carlo simulations and assuming a coefficient of risk aversion of 5. Evaluated at the mean, consumption under the first RMD strategy is too low, resulting in large accumulations of wealth, while wealth accumulation under the second RMD strategy is close to optimal. At the $10^{\text {th }}$ percentile, all the rules of thumb result in slower than optimal wealth decumulation. But the second RMD strategy is closest to the optimal at most ages. At the $90^{\text {th }}$ percentile, the second RMD strategy is very close to optimal at all ages. The first RMD strategy results in excessive wealth accumulation, while households following the 4 per cent rule follow the same wealth trajectory as at the $10^{\text {th }}$ percentile and mean, because they have chosen an all-bond portfolio.

We now compare the above decumulation strategies, assuming typical portfolio allocations, reporting our results in Table 4. Financial wealth is highly unequally distributed. A small minority of households have accumulated large amounts of wealth and likely have an operative bequest motive. A decumulation strategy based on the RMD is unlikely to be appropriate for such households. In contrast, many retired households hold only small amounts of financial assets. For these households, precautionary and liquidity motives will dominate. Using data from the 2008 wave of the HRS, a nationally representative panel data set of older Americans, we calculate the financial wealth, inclusive of IRA and 401(k) balances, of households aged 60-69, who were then entering retirement. We focus on households in the fourth quintile of the distribution of financial wealth, for whom our analysis of HRS data shows had financial wealth from $\$ 78,000$ to $\$ 290,000$ in 2008 . We calculate that the average portfolio allocation of these households was 46 per cent stocks, 8 per cent bonds and 46 per cent short-term deposits. As mentioned previously, we assume that short-term deposits yield a 1 per cent real return. It is unclear why households invest so conservatively. Portfolio allocations could reflect ignorance or habit. But we acknowledge that households could be investing optimally, and that our model mis-specifies preferences.

For married couples and single females who are less risk averse, the second RMD strategy outperforms the three rules of thumb and the purchase of an inflation-indexed annuity. The poor performance of the "spend the interest" strategy reflects the low decumulation rates that are optimal for households whose portfolios are heavily weighted in favour of short-term

${ }^{37}$ Households who purchase inflation-indexed annuity do not have any financial wealth and hence do not need to make portfolio allocation decisions. The portfolio allocation line for this strategy is not shown in the figure. 

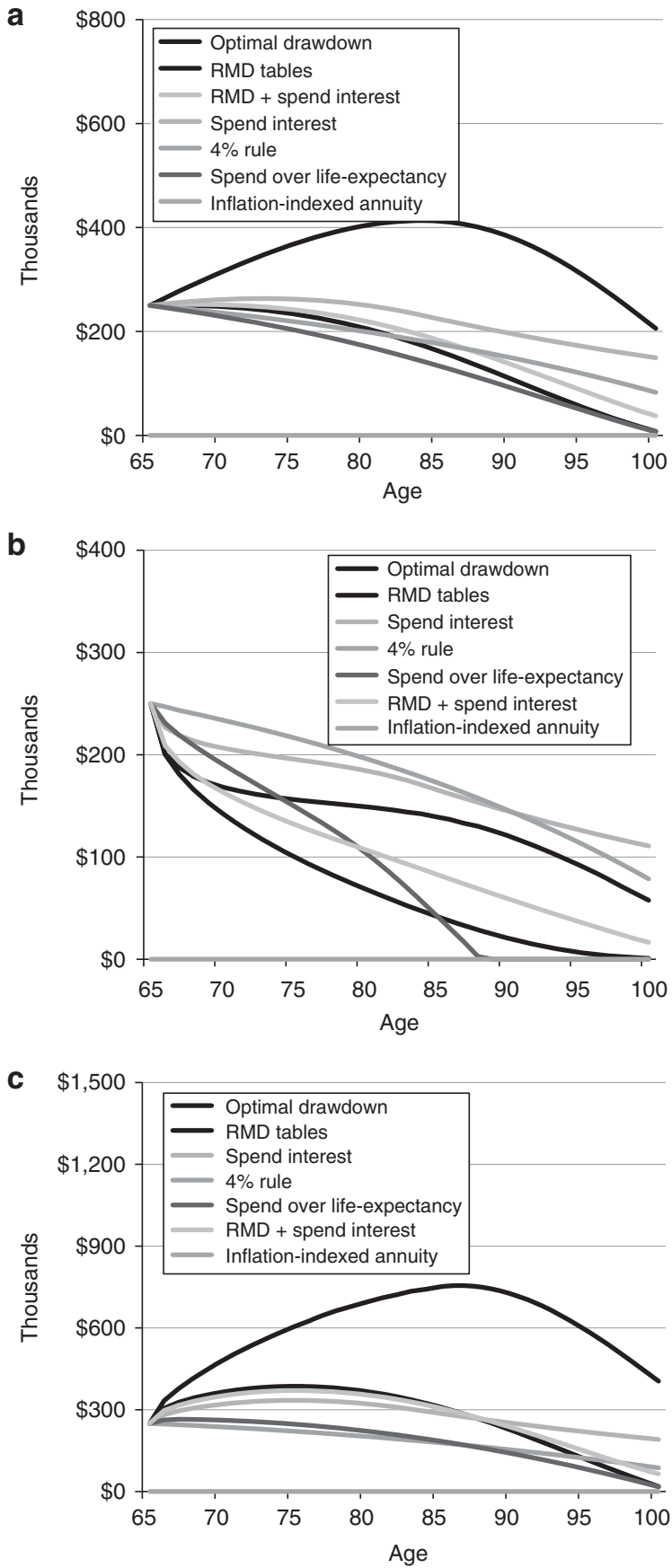

Figure 5. Wealth path of alternative decumulation strategies-Optimal portfolio allocation: (a) Mean; (b) $10^{\text {th }}$ percentile; (c) $90^{\text {th }}$ percentile. 
Table 4 Alternative strategy equivalent wealth—Typical portfolio allocation—Base: Typical portfolio allocation and optimal decumulation

\begin{tabular}{|c|c|c|c|c|c|c|}
\hline \multirow[t]{2}{*}{ Scenario } & \multicolumn{6}{|c|}{ Alternative to optimal drawdown } \\
\hline & $\begin{array}{l}\text { RMD } \\
\text { tables }\end{array}$ & $\begin{array}{c}R M D \\
\text { tables+spend } \\
\text { interest }\end{array}$ & $\begin{array}{l}\text { Spend } \\
\text { interest }\end{array}$ & $4 \%$ rule & $\begin{array}{c}\text { Spend over } \\
\text { life-expectancy }\end{array}$ & $\begin{array}{l}\text { Inflation-indexed } \\
\text { annuity }\end{array}$ \\
\hline \multicolumn{7}{|l|}{ Married couples } \\
\hline \multicolumn{7}{|l|}{ Same age } \\
\hline $\mathrm{CRRA}=2$ & 1.345 & 1.067 & 1.779 & 1.482 & 1.255 & 1.236 \\
\hline $\mathrm{CRRA}=5$ & 1.322 & 1.031 & 1.704 & 1.372 & 1.267 & 1.126 \\
\hline \multicolumn{7}{|c|}{ Wife 6 years younger } \\
\hline $\mathrm{CRRA}=2$ & 1.266 & 1.040 & 1.648 & 1.406 & 1.325 & 1.277 \\
\hline $\mathrm{CRRA}=5$ & 1.246 & 1.020 & 1.588 & 1.329 & 1.290 & 1.164 \\
\hline \multicolumn{7}{|l|}{ Single men } \\
\hline CRRA $=2$ & 1.415 & 1.088 & 1.847 & 1.515 & 1.113 & 1.006 \\
\hline $\mathrm{CRRA}=5$ & 1.354 & 1.038 & 1.732 & 1.372 & NA & 0.889 \\
\hline \multicolumn{7}{|l|}{ Single women } \\
\hline $\mathrm{CRRA}=2$ & 1.302 & 1.051 & 1.728 & 1.442 & 1.141 & 1.078 \\
\hline $\mathrm{CRRA}=5$ & 1.273 & 1.029 & 1.654 & 1.342 & NA & 0.965 \\
\hline
\end{tabular}

Notes: We assume population average mortality for the 1946 birth cohort. For the scenario in which the wife is six years younger than the husband, we assume the account is in the husband's name, and that the wife has population average mortality for the 1952 birth cohort. It is assumed that the husband's Social Security Primary Insurance Amount is $\$ 1,000$, and that the wife is only entitled to a $\$ 500$ spousal benefit per month. The household has $\$ 250,000$ in financial assets, the $70^{\text {th }}$ percentile of the distribution of financial wealth for Health and Retirement Study households aged 60-69 in 2008.

Table 5 Alternative strategy equivalent wealth-Typical portfolio allocation-Base: Optimal portfolio allocation and decumulation

\begin{tabular}{|c|c|c|c|c|c|c|}
\hline \multirow[t]{2}{*}{ Scenario } & \multicolumn{6}{|c|}{ Alternative to optimal drawdown } \\
\hline & $\begin{array}{l}R M D \\
\text { tables }\end{array}$ & $\begin{array}{c}\text { RMD } \\
\text { tables }+ \text { spend } \\
\text { interest }\end{array}$ & $\begin{array}{c}\text { Spend } \\
\text { interest }\end{array}$ & $4 \%$ rule & $\begin{array}{c}\text { Spend over } \\
\text { life-expectancy }\end{array}$ & $\begin{array}{c}\text { Inflation-indexed } \\
\text { annuity }\end{array}$ \\
\hline \multicolumn{7}{|l|}{ Married couples } \\
\hline \multicolumn{7}{|l|}{ Same age } \\
\hline $\mathrm{CRRA}=2$ & 1.621 & 1.300 & 2.176 & 1.799 & 1.528 & 1.498 \\
\hline $\mathrm{CRRA}=5$ & 1.453 & 1.164 & 1.921 & 1.549 & 1.467 & 1.258 \\
\hline \multicolumn{7}{|c|}{ Wife 6 years younger } \\
\hline $\mathrm{CRRA}=2$ & 1.567 & 1.302 & 2.071 & 1.753 & 1.654 & 1.585 \\
\hline $\mathrm{CRRA}=5$ & 1.392 & 1.175 & 1.819 & 1.532 & 1.502 & 1.319 \\
\hline \multicolumn{7}{|l|}{ Single men } \\
\hline $\mathrm{CRRA}=2$ & 1.658 & 1.298 & 2.208 & 1.799 & 1.374 & 1.194 \\
\hline $\mathrm{CRRA}=5$ & 1.463 & 1.160 & 1.927 & 1.532 & NA & 0.986 \\
\hline \multicolumn{7}{|l|}{ Single women } \\
\hline $\mathrm{CRRA}=2$ & 1.566 & 1.286 & 2.114 & 1.754 & 1.411 & 1.309 \\
\hline $\mathrm{CRRA}=5$ & 1.391 & 1.163 & 1.856 & 1.517 & NA & 1.080 \\
\hline
\end{tabular}

Notes: We assume population average mortality for the 1946 birth cohort. For the scenario in which the wife is six years younger than the husband, we assume the account is in the husband's name, and that the wife has population average mortality for the 1952 birth cohort. It is assumed that the husband's Social Security Primary Insurance Amount is $\$ 1,000$, and that the wife is only entitled to a $\$ 500$ spousal benefit per month. The household has $\$ 250,000$ in financial assets, the $70^{\text {th }}$ percentile of the distribution of financial wealth for Health and Retirement Study households aged 60-69 in 2008. 
Table 6 Alternative strategy equivalent wealth—High and low mortality

\begin{tabular}{|c|c|c|c|c|c|c|}
\hline \multirow[t]{2}{*}{ Scenario } & \multicolumn{6}{|c|}{ Alternative to optimal drawdown } \\
\hline & $\begin{array}{l}\text { RMD } \\
\text { tables }\end{array}$ & $\begin{array}{c}\text { RMD } \\
\text { tables+spend } \\
\text { interest }\end{array}$ & $\begin{array}{c}\text { Spend } \\
\text { interest }\end{array}$ & $4 \%$ rule & $\begin{array}{c}\text { Spend over } \\
\text { life-expectancy }\end{array}$ & $\begin{array}{c}\text { Inflation-indexed } \\
\text { annuity }\end{array}$ \\
\hline \multicolumn{7}{|l|}{ Married couples same age } \\
\hline Population average mortality & 1.393 & 1.033 & 1.361 & 1.485 & 1.289 & 1.258 \\
\hline Black-less than high school & 1.445 & 1.036 & 1.371 & 1.501 & 1.454 & 1.301 \\
\hline White_college educated & 1.377 & 1.033 & 1.359 & 1.482 & 1.266 & 1.243 \\
\hline \multicolumn{7}{|l|}{ Single men } \\
\hline Population average mortality & 1.417 & 1.035 & 1.350 & 1.473 & NA & 0.986 \\
\hline Black-less than high school & 1.482 & 1.038 & 1.368 & 1.503 & NA & 1.006 \\
\hline White_college educated & 1.400 & 1.036 & 1.348 & 1.469 & NA & 0.983 \\
\hline \multicolumn{7}{|l|}{ Single women } \\
\hline Population average mortality & 1.333 & 1.029 & 1.320 & 1.427 & NA & 1.080 \\
\hline Black-less than high school & 1.367 & 1.027 & 1.327 & 1.436 & NA & 1.087 \\
\hline White_-college educated & 1.321 & 1.030 & 1.318 & 1.423 & NA & 1.077 \\
\hline
\end{tabular}

Notes: We assume population average mortality for the 1946 birth cohort. For the scenario in which the wife is six years younger than the husband, we assume the account is in the husband's name, and that the wife has population average mortality for the 1952 birth cohort. It is assumed that the husband's Social Security Primary Insurance Amount is $\$ 1,000$, and that the wife is only entitled to a $\$ 500$ spousal benefit per month. The household has $\$ 250,000$ in financial assets, the $70^{\text {th }}$ percentile of the distribution of financial wealth for Health and Retirement Study households aged 60-69 in 2008. We assume the relative mortality rates reported in Brown et al. (2002). We further assume CRRA utility with a coefficient of risk-aversion of 5.

deposits. The 4 per cent rule performs badly because, with typical portfolio allocations, it exposes households to the risk of outliving their wealth, while offering no upside potential.

In Table 5, we calculate the combined effect of choosing a typical portfolio allocation and either a rule of thumb decumulation strategy or one of the two decumulation strategies based on the RMD tables, relative to the base case of choosing both an optimal asset allocation and an optimal drawdown rate. Except for single individuals, who are better off annuitising, the second RMD strategy again dominates the alternatives, but is very considerably suboptimal. We believe it is considerably easier to guide households to an optimal asset allocation, through, for example, life-cycle funds, than to guide them to an optimal decumulation strategy. But there are considerable gains to be achieved by delivering both as a package, relative to allowing households to adopt a typical portfolio allocation and to then follow the second RMD strategy.

Table 6 considers high and low mortality-rate households. We report results for married couples the same age, for single men and for single women who have a coefficient of risk aversion of 5 and choose an optimal portfolio allocation. We show equivalent wealth for whites with a college education, who have lower than average mortality, and blacks with less than a high school education, who have higher than average mortality, relative to the base case reported in Table 3. Relative mortality rates are calculated using the factors reported in 
Brown. ${ }^{38}$ Consistent with Brown, ${ }^{38}$ between-group variations in annual mortality risk have only a small effect on SEW and the second RMD strategy again dominates the three rules of thumb. But within-group variations exceed between-group variations, and the rankings of alternative strategies may differ substantially for particular individuals.

The above calculations all assume that the household lacks an operative bequest motive. When we introduce bequests into the utility function, we find that the RMD strategies are no longer close to optimal, and that for plausible preferences over bequests, the strategy of spending the interest and dividends is close to optimal. These calculations are available from the authors on request. ${ }^{39}$

\section{Conclusions}

The first cohort with substantial amounts of unannutised pension wealth is now entering retirement. They face the challenge of converting that wealth into lifetime income. Almost all households choose not to annuitise and, given the difficulty of calculating an optimal decumulation strategy, will likely fall back on rules of thumb when deciding how rapidly to decumulate their wealth. We show that two of the rules of thumb that households might plausibly adopt-spending the interest and dividends while preserving the capital, and consuming a fixed 4 per cent of initial wealth - can be highly suboptimal. A strategy of spending down over one's life expectancy can work, but only for those with high intertemporal elasticities of consumption who are willing to accept the risk of outliving their wealth.

We find that a strategy of consuming percentages of remaining financial assets, calculated by reference to RMD tables, plus the interest and dividends earned on those assets, is very close to optimal. This finding is robust to alternative assumptions about household type, mortality risk, degree of risk aversion, anticipated investment returns and asset allocation. Importantly, at plausible annuity expense loads, the RMD strategy also dominates the purchase of an inflationindexed annuity for most household types. It is also a strategy that is relatively straightforward to follow. Households aged 70 1/2 with IRAs and 401(k)s already have to calculate RMD withdrawals for income tax purposes. The only additional burden placed on households would be to perform these calculations at younger ages, apply the RMD percentages to non-pension financial assets, and ascertain the interest and dividends earned during the year. This last task could be facilitated by imposing a reporting requirement on financial services companies.

\section{References}

Ameriks, J., Caplin, A., Laufer, S. and Van Nieuwerburgh, S. (2011) 'The joy of giving or assisted living? Using strategic surveys to separate public care aversion from bequest motives', The Journal of Finance 66(2): 519-561. apRoberts, L. (2009) 'Trends in the retirement system of the United States', The Geneva Papers on Risk and Insurance-Issues and Practice 34(4): 618-630.

Bengen, W.P. (1994) 'Determining withdrawal rates using historical data', Journal of Financial Planning 7(4): 171-180. Brown, J.R. (2002) 'Differential Mortality and the Value of Individual Account Retirement Annuities', in M. Feldstein and J.B. Liebman (eds) The Distributional Aspects of Social Security and Social Security Reform, Chicago, IL: University of Chicago Press, pp. 401-446.

\footnotetext{
38 Brown (2002).

${ }^{39}$ Specifically, we assume that bequests enter into the utility function in the manner proposed by Ameriks et al. (2011) and De Nardi (2004).
} 
Brown, J.R., Liebman, J.B. and Pollet, J. (2002) 'Estimating Life Tables that Reflect Socioeconomic Differences in mortality', in M. Feldstein and J.B. Liebman (eds) The Distributional Aspects of Social Security and Social Security Reform, Chicago, IL: University of Chicago Press, pp. 447-457.

Brown, J.R. and Poterba, J.M. (2000) 'Joint life annuities and annuity demand by married couples', The Journal of Risk and Insurance 67(4): 527-553.

Campbell, J.Y. and Viceira, L.M. (2002) 'Who Should Buy Long-term Bonds?' in J.Y. Campbell and L.M. Viceira (eds) Strategic Asset allocation, Oxford, U.K.: Oxford University Press, pp. 48-87.

Chetty, R. (2003) A new method of estimating risk aversion, Working Paper 9988, National Bureau of Economic Research, Cambridge, MA.

Coile, C. and Milligan, K. (2009) 'How household portfolios evolve after retirement: The effect of aging and health shocks', Review of Income and Wealth 55(2): 226-248.

Davidoff, T. (2010) 'Home equity commitment and long-term care insurance demand', Journal of Public Economics 94(1-2): 44-49.

De Nardi, M. (2004) 'Wealth inequality and intergenerational links', The Review of Economic Studies 71(3): $743-768$.

De Nardi, M., French, E. and Jones, J.B. (2010) 'Why do the elderly save? The role of medical expenses', Journal of Political Economy 118(1): 39-75.

Dus, I., Maurer, R. and Mitchell, O.S. (2005) 'Betting on death and capital markets in retirement: A shortfall risk analysis of life annuities versus phased withdrawal plans', Financial Services Review 14(3): 169-196.

Dushi, I. and Webb, A. (2004) 'Household annuitization decisions: Simulations and empirical analyses', Journal of Pension Economics and Finance 3(2): 109-143.

Finke, M., Pfau, W.D. and Williams, D. (2012) 'Spending flexibility and safe withdrawal rates', Journal of Financial Planning 25(3): 44-51.

Heiland, F.W. and Yin, N. (2013) Have we finally achieved actuarial fairness of social security benefits and will it last, unpublished working paper.

Horneff, W.J., Maurer, R.H., Mitchell, O.S. and Dus, I. (2008) 'Following the rules: Integrating asset allocation and annuitization in retirement portfolios', Insurance: Mathematics and Economics 42(1): 396-408.

Horneff, W.J., Maurer, R.H., Mitchell, O.S. and Stamos, M.Z. (2010) 'Variable payout annuities and dynamic portfolio choice in retirement', Journal of Pension Economics and Finance 9(2): 163-183.

Hurd, M.D. (2002) Are bequests accidental or desired, Labor and Population Program Working Paper Series 03-13, Santa Monica, CA: RAND Corporation.

Hurd, M.D. and Rohwedder, S. (2013) 'Wealth dynamics and active saving at older ages', In C. Carroll, T. Crossley and J. Sabelhaus (eds) Improving the Measurement of Consumer Expenditures, Chicago: University of Chicago Press (forthcoming).

Ibbotson Associates (2010) 2010 Ibbotson Stocks, Bonds, Bills, and Inflation (SBBI) Classic Yearbook, Chicago, IL: Morningstar, Inc.

Internal Revenue Service (2012) Social Security and Equivalent Railroad Retirement Benefits, Publication 915. Washington, DC: Internal Revenue Service.

Internal Revenue Service (2013) Individual Retirement Arrangements, Publication 590, Washington, DC: Department of the Treasury, Internal Revenue Service.

Milevsky, M.A. and Huang, H. (2011) 'Spending retirement on Planet Vulcan: The impact of longevity risk aversion on optimal withdrawal rates', Financial Analysts Journal 67(2): 45-58.

Mitchell, O.S., Poterba, J.M., Warshawsky, M.J. and Brown, J.R. (1999) 'New evidence on the money's worth of individual annuities', American Economic Review 89(5): 1299-1318.

Scott, J.S., Sharpe, W.F. and Watson, J.G. (2009) 'The 4\% rule-At what price', Journal of Investment Management 7(3): 31-48.

Social Security Administration (2010) Annual Statistical Supplement. Table 6.B4, SSA Publication No. 13-11700, Washington, DC: Social Security Administration.

Solow, K.R., Kitces, M.E. and Locatelli, S. (2011) 'Improving risk-adjusted returns using market-valuation-based tactical asset allocation strategies', Journal of Financial Planning 24(12): 48-68.

Venti, S.F. and Wise, D.A. (2004) 'Aging and Housing Equity: Another Look', in D.A. Wise (ed.) Perspectives on the Economics of Aging, Chicago, IL: University of Chicago Press, pp. 127-175.

Webb, A. (2009) "Making Your Nest Egg Last a Lifetime," Issue in Brief 9-20, Center for Retirement Research at Boston College, Chestnut Hill, MA.

Yuh, Y. (2011) 'Assessing adequacy of retirement income for U.S. households: A replacement ratio approach', The Geneva Papers on Risk and Insurance -Issues and Practice 36(2): 304-323. 


\section{Appendix}

Table A1 Alternative strategy equivalent wealth-No investment risk

\begin{tabular}{|c|c|c|c|c|}
\hline Scenario & Fixed benefit & Fixed percentage & $1 / T$ & $1 / E(T)$ \\
\hline \multicolumn{5}{|l|}{ Married couples } \\
\hline \multicolumn{5}{|l|}{ Same age } \\
\hline $\mathrm{CRRA}=2$ & 1.127 & 1.264 & 1.423 & 1.088 \\
\hline $\mathrm{CRRA}=5$ & 1.106 & 1.201 & 1.380 & 1.064 \\
\hline \multicolumn{5}{|c|}{ Wife 6 years younger } \\
\hline $\mathrm{CRRA}=2$ & 1.141 & 1.254 & 1.469 & 1.109 \\
\hline CRRA $=5$ & 1.108 & 1.193 & 1.448 & 1.083 \\
\hline \multicolumn{5}{|l|}{ Single men } \\
\hline $\mathrm{CRRA}=2$ & 1.043 & 1.211 & 1.511 & 1.018 \\
\hline $\mathrm{CRRA}=5$ & 2.351 & 1.152 & 1.424 & 1.041 \\
\hline \multicolumn{5}{|l|}{ Single women } \\
\hline $\mathrm{CRRA}=2$ & 1.040 & 1.233 & 1.369 & 1.021 \\
\hline CRRA $=5$ & 1.276 & 1.191 & 1.330 & 1.031 \\
\hline
\end{tabular}

Notes: We assume population average mortality for the 1946 birth cohort. For the scenario in which the wife is six years younger than the husband, we assume the account is in the husband's name, and that the wife has population average mortality for the 1952 birth cohort. It is assumed that the husband's Social Security Primary Insurance Amount is $\$ 1,000$, and that the wife is only entitled to a $\$ 500$ spousal benefit per month. The household has $\$ 250,000$ in financial assets, the $70^{\text {th }}$ percentile of the distribution of financial wealth for Health and Retirement Study households aged 60-69 in 2008. Consistent with Dus et al. (2005), households consume a fixed benefit each period under fixed benefit strategy and they consume a fixed percentage of remaining wealth under fixed percentage strategy. Fixed benefit is set at the annuity payment and fixed percentage equals the initial payment of annuity for $\$ 1$ premium.

Table A2 Alternative strategy equivalent wealth-Optimal portfolio allocation

\begin{tabular}{|c|c|c|c|c|}
\hline Scenario & Fixed benefit & Fixed percentage & $1 / T$ & $1 / E(T)$ \\
\hline \multicolumn{5}{|l|}{ Married couples } \\
\hline \multicolumn{5}{|l|}{ Same age } \\
\hline $\mathrm{CRRA}=2$ & 1.512 & 1.258 & 1.464 & 1.102 \\
\hline $\mathrm{CRRA}=5$ & 1.300 & 1.222 & 1.519 & 1.127 \\
\hline \multicolumn{5}{|c|}{ Wife 6 years younger } \\
\hline $\mathrm{CRRA}=2$ & 1.595 & 1.248 & 1.525 & 1.129 \\
\hline $\mathrm{CRRA}=5$ & 1.347 & 1.219 & 1.621 & 1.165 \\
\hline \multicolumn{5}{|l|}{ Single men } \\
\hline $\mathrm{CRRA}=2$ & 1.268 & 1.206 & 1.554 & 1.022 \\
\hline $\mathrm{CRRA}=5$ & 1.366 & 1.163 & 1.551 & 1.045 \\
\hline \multicolumn{5}{|l|}{ Single women } \\
\hline $\mathrm{CRRA}=2$ & 1.352 & 1.229 & 1.416 & 1.031 \\
\hline $\mathrm{CRRA}=5$ & 1.243 & 1.197 & 1.450 & 1.049 \\
\hline
\end{tabular}

Notes: We assume population average mortality for the 1946 birth cohort. For the scenario in which the wife is six years younger than the husband, we assume the account is in the husband's name, and that the wife has population average mortality for the 1952 birth cohort. It is assumed that the husband's Social Security Primary Insurance Amount is $\$ 1,000$, and that the wife is only entitled to a $\$ 500$ spousal benefit per month. The household has $\$ 250,000$ in financial assets, the $70^{\text {th }}$ percentile of the distribution of financial wealth for Health and Retirement Study households aged 60-69 in 2008. Consistent with Dus et al. (2005), households consume a fixed benefit each period under fixed benefit strategy and they consume a fixed percentage of remaining wealth under fixed percentage strategy. Fixed benefit is set at the annuity payment and fixed percentage equals the initial payment of annuity for $\$ 1$ premium. 
Table A3 Alternative strategy equivalent wealth-Typical portfolio allocation

\begin{tabular}{lcccc}
\hline Scenario & Fixed benefit & Fixed percentage & $1 / T$ & $1 / E(T)$ \\
\hline $\begin{array}{l}\text { Married couples } \\
\text { Same age }\end{array}$ & & & & \\
$\quad$ CRRA=2 & 1.283 & 1.257 & 1.430 & 1.089 \\
$\quad$ CRRA=5 & 1.284 & 1.207 & 1.433 & 1.087 \\
$\quad$ Wife 6 years younger & & & & \\
$\quad$ CRRA=2 & 1.320 & 1.245 & 1.478 & 1.109 \\
$\quad$ CRRA=5 & 1.299 & 1.198 & 1.513 & 1.112 \\
Single men & & & & \\
$\quad$ CRRA=2 & 1.136 & 1.207 & 1.519 & 1.018 \\
CRRA=5 & 2.332 & 1.159 & 1.475 & 1.041 \\
Single women & & & & \\
CRRA=2 & 1.177 & 1.228 & 1.379 & 1.023 \\
CRRA=5 & 1.499 & 1.191 & 1.376 & 1.035 \\
\hline
\end{tabular}

Notes: We assume population average mortality for the 1946 birth cohort. For the scenario in which the wife is six years younger than the husband, we assume the account is in the husband's name, and that the wife has population average mortality for the 1952 birth cohort. It is assumed that the husband's Social Security Primary Insurance Amount is $\$ 1,000$, and that the wife is only entitled to a $\$ 500$ spousal benefit per month. The household has $\$ 250,000$ in financial assets, the $70^{\text {th }}$ percentile of the distribution of financial wealth for Health and Retirement Study household's aged 60-69 in 2008. Consistent with Dus et al. (2005), households consume a fixed benefit each period under fixed benefit strategy and they consume a fixed percentage of remaining wealth under fixed percentage strategy. Fixed benefit is set at the annuity payment and fixed percentage equals the initial payment of annuity for $\$ 1$ premium.

\section{About the Authors}

Wei Sun is an Assistant Professor at Hanqing Advanced Institute of Economics and Finance, Renmin University of China. He joined the institute in 2010, after obtaining his PhD in Economics at Boston College. He earned his MA in Economics and MS in Applied Statistics at Bowling Green State University, and his BA in Finance at the University of International Business and Economics, Bejing. His research focuses on ageing, social security, pensions and long-term care.

Anthony Webb earned his doctorate in economics from the University of California, San Diego, in 2001. He holds a BA in industrial economics from the University of Nottingham (1975) and an MA in economics from the University of Manchester (1994). Prior to commencing his doctorate, Dr Webb was employed by the British government, providing policy advice on taxation of personal savings. His published work includes investigations of the impact of pensions on retirement and studies of retirement asset decumulation. 